\title{
Expression and Modulation of Nerve Growth Factor in Murine Keratinocytes (PAM 212)
}

\author{
V. A. Tron, ${ }^{*}$ M. D. Coughlin, ${ }^{\ddagger}$ D. E. Jang, ${ }^{\ddagger}$ J. Stanisz, ${ }^{\ddagger}$ and D. N. Sauder ${ }^{\star}$ \\ Departments of Medicine* and Neurosciences, ${ }^{\ddagger}$ McMaster University, Hamilton, Ontario L8N 3Z5, Canada
}

\begin{abstract}
Nerve growth factor (NGF) is a polypeptide that is required for normal development and maintenance of the sympathetic and sensory nervous systems. Skin has been shown to contain relatively high amounts of NGF, which is in keeping with the finding that the quantity of NGF in a tissue is proportional to the extent of sympathetic innervation of that organ. Since the keratinocyte, a major cellular constituent of the skin, is known to produce other growth factors and cytokines, our experiments were designed to determine whether keratinocytes are a source of NGF. Keratinocyte-conditioned media from the keratinocyte cell line PAM 212 contained NGF-like activity, $\sim 2-3 \mathrm{ng} / \mathrm{ml}$, as detected by the neurite outgrowth assay. Freshly isolated BALB/c keratinocytes contained $\sim 0.1$ $\mathrm{ng} / \mathrm{ml}$. Using a cDNA probe directed against NGF, we demonstrated the presence of a 1.3-kb NGF mRNA in both PAM 212 and BALB/c keratinocytes. Since ultraviolet radiation (UV) is a potentially important modulating factor for cytokines in skin, we examined the effect of UV on NGF mRNA expression. Although $U V$ initially inhibited the expression of keratinocyte NGF mRNA (4 h), by $24 \mathrm{~h}$ an induction of NGF mRNA was seen. The NGF signal could also be induced by phorbol esters. Thus, keratinocytes synthesize and express NGF, and its expression is modulated by UVB and phorbol esters. (J. Clin. Invest. 1990. 85:1085-1089.) nerve growth factor • cytokines • keratinocytes
\end{abstract}

\section{Introduction}

Skin was thought, until recently, to function only as a protective barrier. However, that concept has changed with the discovery that within skin, the keratinocyte is now known to produce many growth factors and cytokines that function to maintain normal homeostasis.

Nerve growth factor (NGF) ${ }^{1}$ is a 118 -amino acid dimer encoded by a $1.3-\mathrm{kb}$ mRNA $(1,2)$. The protein sequence for NGF has been known for 17 years, and this information allowed for the cloning of mouse NGF and human NGF cDNA (3). NGF isolated from the murine salivary gland under physi-

Address reprint requests to Dr. Sauder, Department of Medicine, McMaster University, HSC-Room 3V46, 1200 Main Street West, Hamilton, Ontario L8N 3Z5, Canada.

Received for publication 25 August 1988 and in revised form 30 November 1989.

1. Abbreviations used in this paper: CM, conditioned medium; NGF, nerve growth factor; SCG, superior cervical ganglia; UV, ultraviolet radiation.

J. Clin. Invest.

(C) The American Society for Clinical Investigation, Inc.

0021-9738/90/04/1085/05 \$2.00

Volume 85, April 1990, 1085-1089 ological conditions exists in the $7 \mathrm{~S}$ form and is composed of $\alpha$, $\beta$, and $\gamma$ subunits (4). Biological activity resides in the $\beta$ subunit (2.5S NGF). It is clear that NGF is important in the development and maintenance of sensory and sympathetic neurons (5). However, its effects are much more diverse, such as its effects on the immune system. For example, NGF induces mast cell hyperplasia and mast cell degranulation $(6,7)$, and the proinflammatory cytokine interleukin 1 is known to induce NGF mRNA in sciatic nerve explants (8).

NGF is found in greatest abundance in those tissues with extensive sympathetic innervation $(9,10)$. Using a sensitive ELISA assay, whole-skin extracts have been shown to contain relatively high levels of immunoreactive NGF (11). Using Northern and in situ hybridization techniques Davies has shown that the epidermis of murine embryos expressed most of the NGF in the skin (12). By inference, since the keratinocyte is the most abundant cell in the epidermis, this study suggested that keratinocytes are the source of NGF.

The purpose of these experiments was to determine whether keratinocytes produce NGF and to study factors modulating such synthesis.

\section{Methods}

Cells. The PAM 212 cell line is a spontaneously transformed newborn BALB/c-derived keratinocyte line (13), which was used as a source of keratinocytes. The cell line was maintained in Dulbecco's MEM, 10\% fetal calf serum, $2 \% \mathrm{~L}$-glutamine, $1 \%$ penicillin and streptomycin, and $1 \mathrm{mM}$ Hepes at $37^{\circ} \mathrm{C}$ in $5 \% \mathrm{CO}_{2}$.

Normal murine BALB/c epidermal cells were prepared from 6-wk-old mice by trypsinization of whole skin as previously described (14). Conditioned medium (CM) from the above cells was obtained after $3 \mathrm{~d}$ in culture and tested in the bioassay.

Bioassay. Details of the biological assay for NGF have been previously described (15). Briefly, superior cervical ganglia (SCG) were dissected from newborn mice or 15-d gestational embryos (E15), dissociated with trypsin, and cells $(\sim 20,000$ cells per dish) plated onto $35-\mathrm{mm}$ polyornithine- or collagen- and polyornithine-coated petri dishes. Newborn mouse sympathetic neurons have an absolute requirement for NGF and do not survive in culture if deprived of it. In contrast, E15 sympathetic neurons have not totally developed a requirement for NGF and many survive in culture even in the presence of anti-NGF, as long as a neurite-promoting factor is provided (16). For some assays, medium conditioned over PAM 212 cells was added directly to dishes. In other experiments, PAM-CM was passed through a DEAE agarose column to remove substrate-binding, neurite-promoting factors (15). CM from BALB/c epidermal cell cultures was concentrated 10 -fold by ultrafiltration using an ultrafiltration unit with a YM-10 filter (Amicon Corp., Danvers, MA). The concentrated CM was then passed through a Sephacryl S-200 column to separate high molecular mass $(>65 \mathrm{kD})$ and lower molecular mass $(<65 \mathrm{kD})$ components. These components were then reconcentrated to the original concentration and tested in the bioassay. After $20 \mathrm{~h}$ of incubation at $37^{\circ} \mathrm{C}$, cell counts were performed using phase-contrast microscopy. Phase-bright cells with processes greater than one cell diameter were counted on $2 \%$ of the dish. 
2.5 $S$ NGF and antisera. NGF was isolated in the $2.5 \mathrm{~S}$ form from murine submaxillary glands using a modification (17) of the method of Mobley et al. (18). Antisera to 2.5 S NGF (anti-NGF) were prepared in New Zealand white rabbits and its titer and specificity were determined as previously described (17).

Western blotting. NGF-like material from PAM-CM was isolated by affinity chromatography on an anti-NGF affinity column as described (18). Eluted material was dialized for $16 \mathrm{~h}$ against three changes of water and lyophilized. Aliquots of the eluted material along with authentic NGF were analyzed by electrophoresis on $15 \%$ polyacrylamide gels under reducing conditions in the presence of SDS, transferred overnight to nitrocellulose paper, incubated with ${ }^{125}$ I-labeled monoclonal anti-NGF, and subjected to autoradiography, all as previously described (18)

$R N A$ blotting. Total RNA was isolated over a cesium chloride gradient by ultracentrifugation (19). Poly (A) RNA was collected by passing total RNA over an oligo $\mathrm{d}(\mathrm{T})$ cellulose column; average yields were $3 \%$ of total RNA (19). For Northern analysis $3 \mu \mathrm{g}$ of RNA was electrophoresed in $1 \%$ agarose, $6.6 \%$ formaldehyde, and transferred to nitrocellulose (19). Gels were electrophoresed until bromophenol blue was two-thirds of the way to the bottom of the gel $(\sim 4 \mathrm{~h})$. Slot blots were performed by spotting RNA directly onto nitrocellulose.

Blots were prehybridized for $2 \mathrm{~h}$ at $48^{\circ} \mathrm{C}$ in $50 \%$ formamide, $5 \times$ SSC $(1 \times$ SSC $=0.15 \mathrm{M}$ sodium chloride, $0.015 \mathrm{M}$ sodium citrate, $\mathrm{pH}$ $7.0), 5 \times$ Denhardt's solution ( $0.1 \%$ Ficoll, $0.1 \%$ polyvinyl pyrol iodine, $0.1 \%$ BSA $), 0.5 \times \mathrm{P}$ wash $\left(10 \times \mathrm{P}\right.$ wash $=1 \mathrm{M} \mathrm{Na}_{2} \mathrm{HPO}_{4}, 0.1 \mathrm{M}$ $\left.\mathrm{Na}_{2} \mathrm{H}_{2} \mathrm{P}_{2} \mathrm{O}_{7}\right), 250 \mu \mathrm{g} / \mathrm{ml}$ salmon sperm DNA, $0.1 \%$ SDS. Hybridization buffer was identical to above, but with labeled probe added. Washing was done in $2 \times \mathrm{SSC} / 0.1 \%$ SDS at room temperature for 60 min, and $0.1 \times \mathrm{SSC} / 0.1 \% \mathrm{SDS}$ at $48^{\circ} \mathrm{C}$ for $30 \mathrm{~min}$. All films were autoradiographed on XAR film (Eastman Kodak Co., Rochester, NY) at $-70^{\circ} \mathrm{C}$.
Oligo (dT) normalization. To ensure equivalent amounts of mRNA were present on the blots, oligo (dT) normalization was done (20). Blots were hybridized in $5 \times$ SSC, $5 \times$ Denhardt's, $0.1 \times P$ wash, and $40 \mathrm{pmol}$ labeled oligo (dT) at room temperature for $1 \mathrm{~h}$. Washes were done in $2 \times$ SSC for $20 \mathrm{~min}$.

Labeling of probes. A murine NGF single-stranded cDNA probe (9), a kind gift of David L. Shelton (University of California, San Francisco), was mixed oligo-labeled using ${ }^{32}[\mathrm{P}] \mathrm{dCTP}$ according to the protocol of Feinberg (21). Specific activities of $1-2 \times 10^{9} \mathrm{dpm} / \mu \mathrm{g}$ were achieved. Oligo $(\mathrm{dT})_{18}$ was ${ }^{32} \mathrm{P}$-labeled using $\mathrm{T}_{4}$ kinase as previously described (20)

Ultraviolet (UV) irradiation. PAM 212 cells were UV irradiated using Westinghouse Sunlamps (National Biological Corp., Twinsburg, $\mathrm{OH})$. Energy output was confirmed using a spectroradiometer. Subconfluent keratinocytes in 10-cm petri dishes (Becton, Dickinson \& Co., Oxnard, CA) were washed three times with PBS and irradiated with varying amounts of $U V, 10 \mathrm{ml}$ of media was added, and dishes were returned to the incubator. At specified times, post-irradiated cells were harvested by adding $4 \mathrm{M}$ guanidinium isothiocyanate directly to the dishes and slot blot analysis was performed as previously described.

\section{Results}

Bioassay. In order to determine whether keratinocytes produced NGF a biological assay was employed. Keratinocyteconditioned medium (PAM-CM), which was generated using PAM 212 cells in Dulbecco's MEM, 10\% FCS over a period of $4 \mathrm{~d}$, induced significant neurite outgrowth from E15 SCG neurons as compared with control unconditioned media (Fig. 1). E15 neurons were used initially because they respond not only to NGF, but to other neurotrophic factors present in CM
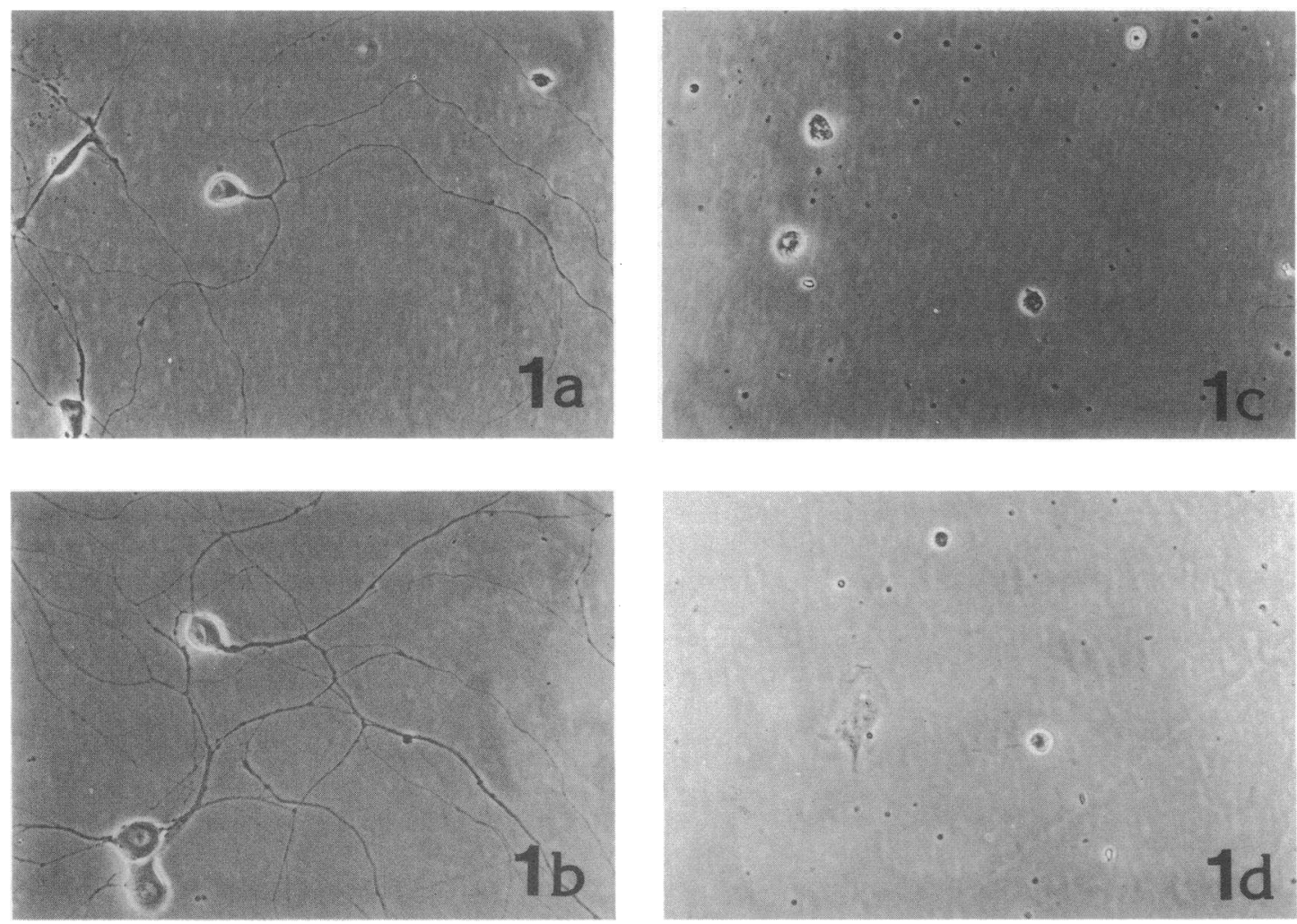

Figure 1. NGF biological assay of keratinocyte-CM. Superior cervical ganglia were isolated from newborn mice, trypsinized, plated onto polyornithine-coated dishes and then cultured in the following experimental conditions for $20 \mathrm{~h}:(1 a) 50 \% \mathrm{KCM},(1 b) 2.5 \mathrm{~S} \mathrm{NGF}(50 \mathrm{ng} / \mathrm{ml}),(1 c)$ $2.5 \mathrm{~S} \mathrm{NGF}(50 \mathrm{ng} / \mathrm{ml})$ plus anti-NGF $(0.1 \%),(1 d)$ control medium alone. Keratinocyte-CM $(l a)$ was capable of inducing significant neurite outgrowth, comparable to that of the positive control $(l b)$. The addition of anti-NGF $(I c)$ was capable of inhibiting neurite outgrowth. Unconditioned medium $(1 d)$ could not induce neurite outgrowth. Phase-contrast photomicrographs $(\times 40)$. 
(16). A dose-dependent response was observed when serial dilutions of PAM-CM were added to the system; addition of $0.1 \%$ anti-NGF to dilutions of PAM-CM inhibited neurite outgrowth $\sim 50 \%$ (Fig. 2), suggesting that the NGF released by keratinocytes acting as one of the $\mathrm{CM}$ neurotrophic factors.

To determine the amount of NGF activity in $\mathrm{KCM}$, we used newborn SCG neurons on a collagen substrate to avoid any contribution to survival which might be due to the modifying effect of substrate-binding, neurite-promoting factors (16). PAM-CM was passed through a DEAE column to remove such neurite-promoting factor(s) (15). To test for NGF release by normal murine epidermal cells, BALB/c epidermal cell CM was separated into high and low molecular mass fractions to facilitate concentration of the proteins. Although some NGF activity could be detected in epidermal cell CM that had not been concentrated, it was necessary to concentrate the epidermal cell CM in order to quantify activity.

Both PAM-CM and BALB/c CM exhibited NGF-like activity that was completely inhibited by $0.1 \%$ antiserum to NGF (Fig. 3). Based on a standard curve using 7 S NGF, PAM-CM was found to contain $2-3 \mathrm{ng} / \mathrm{ml}$ NGF. Only the high molecular mass fraction of BALB/c CM was found to contain NGF activity, with the amount of activity corresponding to $\sim 0.1$ $\mathrm{ng} / \mathrm{ml} \mathrm{NGF}$ in the medium before concentration.

Western analysis. To further characterize the NGF-like activity in PAM-CM, CM was passed through an anti-NGF affinity column and bound material was subjected to gel electrophoresis 125 and Western blotting with ${ }^{125}$ I-labeled monoclonal anti-NGF. NGF-like material from PAM-CM migrated identically to authentic $2.5 \mathrm{~S}$ NGF (Fig. 4).

Northern analysis. To determine whether keratinocytes express mRNA coding for NGF, Northern analysis was used. Poly (A) selected RNA from PAM 212 cells demonstrated a single band at the expected size of $1.3 \mathrm{~kb}$ consistent with NGF (Fig. 5, left), while total keratinocyte RNA showed a very weak

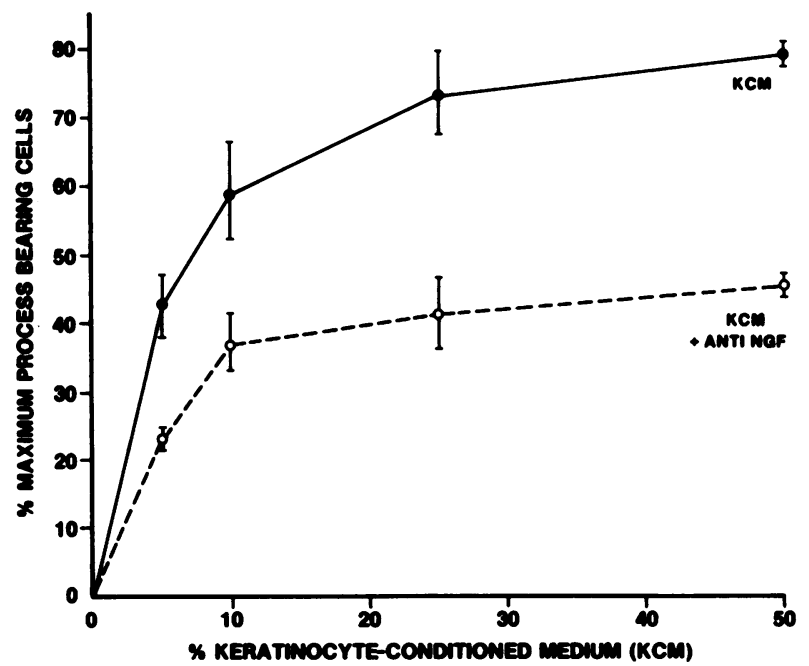

Figure 2. Effect of anti-NGF in the neurite outgrowth assay of keratinocyte-conditioned medium (KCM). E15 superior cervical ganglia were dissociated and added to culture dishes containing decreasing concentrations of KCM (๑) or KCM plus anti-NGF (o) were added. After $20 \mathrm{~h}$ of incubation, the number of phase-bright cells bearing processes were counted and expressed as a percentage of maximum (i.e., the number of neurite-bearing cells surviving in the presence of $10 \mathrm{ng} / \mathrm{ml} \mathrm{NGF}$ and $25 \mu \mathrm{g} / \mathrm{ml}$ purified neuronectin). Each value represent the mean \pm SEM of three culture dishes.

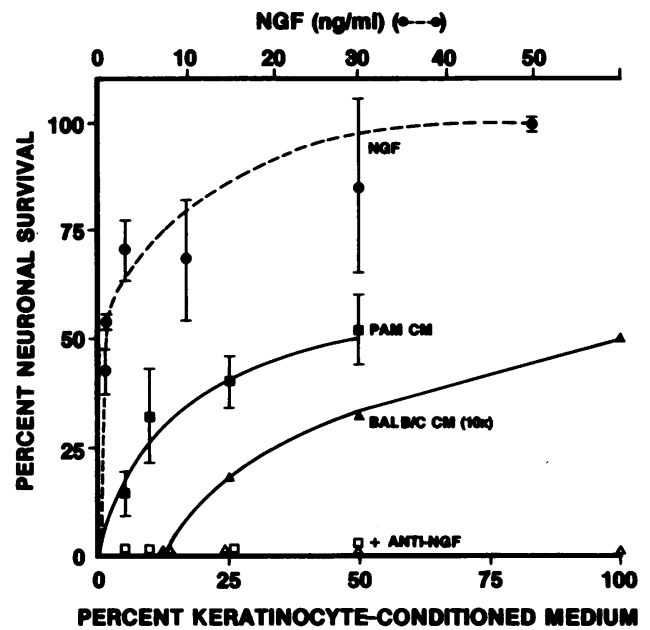

Figure 3. Quantitation of NGF-like activity from PAM-CM and normal BALB/c keratinocyte-CM (Balb/c-CM). Dissociated superior cervical ganglia neurons from newborn mice were plated onto collagen- and polyornithine-coated culture dishes containing decreasing concentrations of PAM-CM (a) or PAM-CM + anti-NGF (ם), BALB/c-CM ( $\Delta)$ or BALB/c CM + anti-NGF $(\Delta)$. Cell survival was determined as in Fig. 2 after $20 \mathrm{~h}$ of incubation. Each value for the PAM-CM curve represents the mean \pm SEM of three separate dishes. For the BALB/c CM, values are for the 10 -fold concentrated $C M$, and represent duplicate cultures. Also shown is the NGF dose-response curve (๑), used to quantify the NGF in CM. From this curve the half-maximal value for neuronal survival can be seen to be equivalent to $\sim 1 \mathrm{ng} / \mathrm{ml}$ NGF. This point intersects the PAM-CM curve at $50 \%$, thus PAM-CM contains $\sim 2 \mathrm{ng} / \mathrm{ml} \mathrm{NGF}$.

band on an overnight exposure. RNA from salivary glands was used as the positive control and showed a single band at $1.3 \mathrm{~kb}$. Normal murine epidermal cells also demonstrated a 1.3-kb band consistent with NGF (Fig. 5, right).

$U V$ radiation. $\mathrm{UV}$ radiation is known to modulate certain cytokines in keratinocytes, therefore, the effects of UVB on

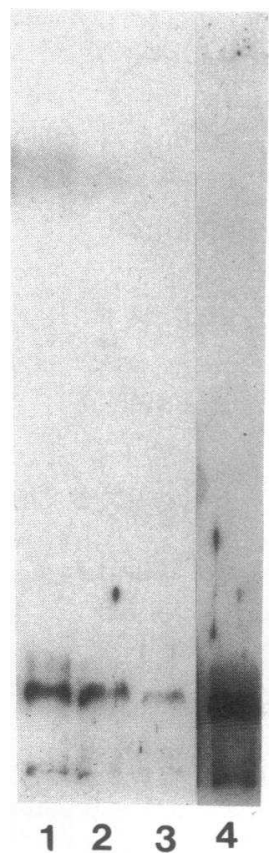

Figure 4. Immunoblot analysis of PAM-CM NGF-like material after electrophoresis. 500 $\mathrm{ml}$ of medium containing $1 \%$ fetal bovine serum was passed through an anti-NGF affinity column as described in Methods. The lyophilized eluate was solubilized in electrophoresis sample buffer and one-fourth of the total was applied to the gel. Western blotting is described in Methods. Lanes 1, 2, and 3 contain 5, 2, and $1 \mu \mathrm{g} 2.5 \mathrm{~S} \mathrm{NGF,} \mathrm{respec-}$ tively, Lane 4 contains the NGF-like material from PAM-CM. 


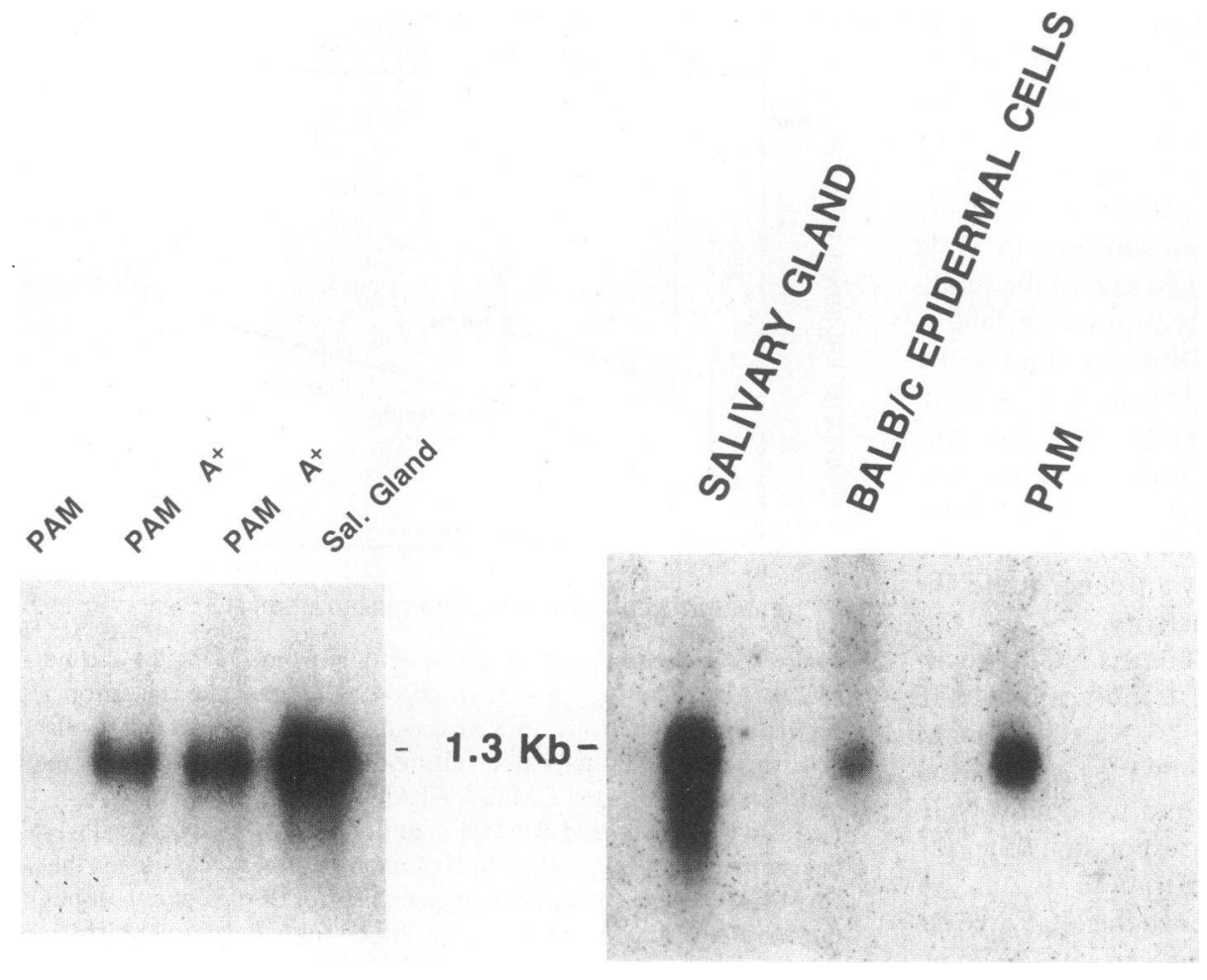

Figure 5. (Left) Northern analysis of NGF mRNA. RNA was prepared over a cesium chloride gradient, fractionated on a $1 \%$ agarose $/ 6.6 \%$ formaldehyde gel, transferred to nitrocellulose, and probed with NGF cDNA. Lanes are designated as follows: $P A M$ (PAM 212 murine keratinocyte cell line), $P A M A^{+}$[poly(A) ${ }^{+}$selected PAM RNA], Sal. gland (male murine salivary gland). The indicated size of the mRNA was relative to DNA size markers. (Right) Northern analysis of NGF mRNA. Lanes are designated as follows: Salivary gland (total RNA from male murine salivary gland), $B A L B / c$ epidermal cells, and $P A M .3$ $\mu \mathrm{g}$ of each was applied to gel.

keratinocytes NGF mRNA was examined. Some change in NGF mRNA was observed in unirradiated keratinocytes between 4 and $24 \mathrm{~h}$, however, in all experiments (four out of four) there was a consistent decrease in HGF mRNA at $4 \mathrm{~h}$ after UV exposure and an increase $24 \mathrm{~h}$ after UV exposure (Fig. 6). Oligo (dT) normalization revealed equivalent amounts of RNA were present. Signal strength was confirmed

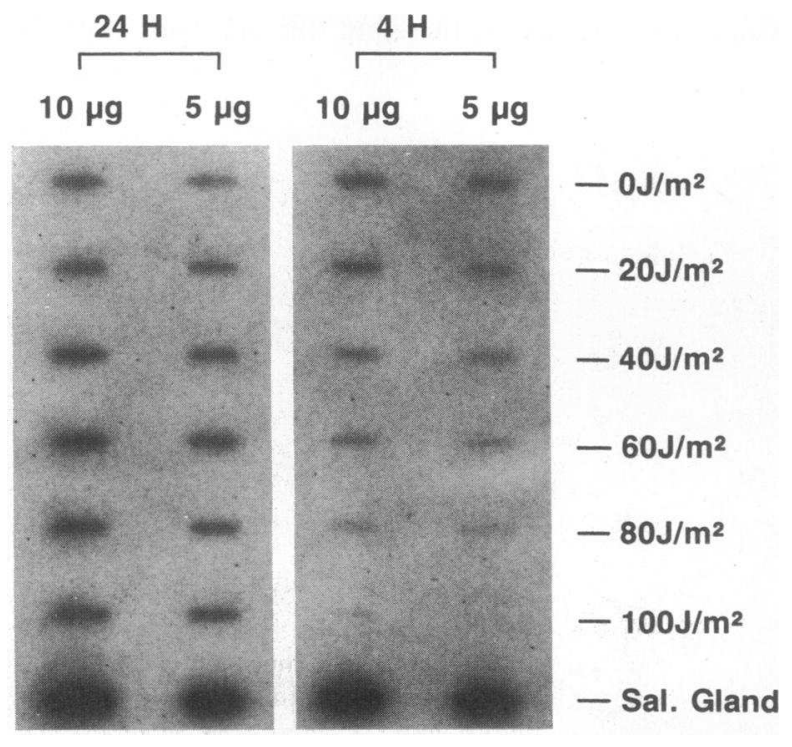

Figure 6. Effect of UVB on keratinocyte NGF mRNA expression. PAM 212 keratinocytes were exposed to increasing amounts of UV $\left(0-100 \mathrm{~J} / \mathrm{m}^{2}\right)$, then harvested using guaunidinium isothiocyanate. RNA was prepared over cesium chloride, and 5 and $10 \mu \mathrm{g}$ of total RNA was blotted directly onto nitrocellulose and probed with a NGF cDNA. NGF mRNA expression 4 and $24 \mathrm{~h}$ after UV exposure is shown. with a densitometer. A representative experiment revealing a fourfold reduction in signal at $4 \mathrm{~h}$ and a twofold induction at $24 \mathrm{~h}$ is shown in Fig. 6.

Effect of phorbol esters. PMA $(20 \mathrm{ng} / \mathrm{ml})$ was added to PAM 212 keratinocytes for a period of $6 \mathrm{~h}$ and slot blot analysis for NGF mRNA was done. PMA consistently induced keratinocyte NGF mRNA as compared with diluent control (five out of five experiments). A representative experiment with a 1.6-fold induction in NGF mRNA is shown in Fig. 7.

\section{Discussion}

In this report we have shown that keratinocytes synthesize and express NGF in vitro. This observation appears to be consistent with data presented by Davies et al. (12) who observed that within embryonic skin, the epidermis contained high levels of NGF. Since the keratinocyte is the major cell within the epidermis, it likely represents the cell of origin. Rabbit corneal epithelial cultures were have been shown to produce a NGF-like substance (22), but ours is the first report showing keratinocytes secrete NGF and express NGF mRNA.

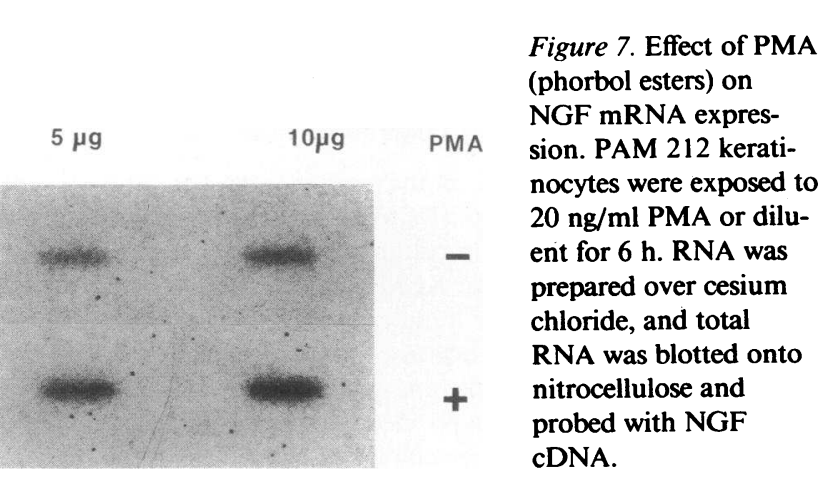

Figure 7. Effect of PMA (phorbol esters) on sion PAM 212 keratinocytes were exposed to $20 \mathrm{ng} / \mathrm{ml}$ PMA or dilunitrocellulose and cDNA. 
Using a well-characterized biological assay, based on the ability of NGF to promote survival and neurite extension in neurons, keratinocyte-CM was shown to contain high levels of activity. Since it is known that molecules other than NGF induce neurite outgrowth (1.5), identification of the activity as NGF required inhibition with anti-NGF antibody. Specific anti-NGF antisera only partially inhibited survival of E15 neurons plated in KCM. This is consistent with the presence in $\mathrm{CM}$ of two complementary growth factors, neuronectin and NGF. Since E15 SCG neurons do not yet completely require NGF for survival, only partial inhibition would be expected (15). On the other hand, newborn SCG neurons exhibit an absolute requirement for NGF in a dose-dependent manner. In order to quantify the amount of NGF present in the medium, we used the standard assay with newborn SCG neurons on collagen-coated dishes. PAM-CM depleted of neuronectin by passage over a DEAE column was shown to contain $\sim 2-3$ $\mathrm{ng} / \mathrm{ml}$ of NGF-like activity as determined by biological assay. Since anti-NGF antiserum completely blocked activity, it is most likely that the activity is attributable to NGF. In fact, material bound to an anti-NGF affinity column appeared identical to authentic 2.5S NGF upon gel electrophoresis and immunoblotting. Similar experiments with normal keratinocytes from BALB/c mice revealed that normal keratinocytes produced NGF protein and exhibited NGF mRNA, although both protein and mRNA levels in normal keratinocytes were lower ( $\sim 10$-fold) that those found in PAM 212 cells. NGF protein has also been observed in human keratinocytes (23).

Ultraviolet radiation is known to have a multiplicity of effects on organisms in vitro and in vivo. UV is also known to modulate other cytokines on a transcriptional level $(24,25)$. Our data shows an initial inhibition of NGF mRNA then an induction of NGF mRNA at $24 \mathrm{~h}$ after UV exposure. Phorbol esters are also capable of inducing expression of a variety of cytokines. Our data also demonstrates that keratinocyte NGF is induced by PMA. It is known that PMA exposure induces NGF receptors in melanocytes (26), thus a potential mechanism exists whereby PMA can induce keratinocyte NGF and melanocyte NGF receptors.

In conclusion, we have shown that keratinocytes from PAM 212 cells and BALB/c cells express and secrete NGF, and its expression is modulated by UVB and phorbol esters.

\section{Acknowledgments}

This work was supported in part by the Ontario Ministry of Health, Medical Research Council, Canadian Dermatology Foundation, and National Institutes of Health (NS-19573).

\section{References}

1. Levi-Montalcini, R. 1987. The nerve growth factor 35 years later. Science (Wash. DC). 237:1154-1162.

2. Scott, J., M. Selby, M. Urdea, M. Quiroga, G. I. Bell, and W. J. Rutter. 1983. Isolation and nucleotide sequence of a cDNA encoding the precursor of mouse nerve growth factor. Nature (Lond.). 302:538540 .

3. Ulrich, A., A. Gray, C. Berman, and T. J. Dull. 1983. Human $\beta$-nerve growth factor gene sequence highly homologous to that of mouse. Nature (Lond.). 303:821-825.

4. Greene, L. A., and E. M. Shooter. 1980. The nerve growth factor: biochemistry, synthesis, and mechanism of action. Annu. Rev. Neurosci. 3:353-402.

5. Thoenen, H., and Y. A. Barde. 1980. Physiology of nerve growth factor. Physiol. Rev. 60:1284-1335.
6. Aloe, K., and R. Levi-Montalcini. 1977. Mast cell increase in tissue of neonatal rats injected with nerve growth factor. Brain Res. 133:358-366.

7. Bienenstock, J., M. Tomioka, H. Matsuda, R. H. Stead, G. Quinonez, G. T. Simon, M. D. Coughlin, and J. A. Denburg. 1987. The role of mast cells in inflammatory processes: evidence for nerve/ mast cell interactions. Int. Arch. Allergy Appl. Immunol. 82:238-243.

8. Lindholm, D., R. Heumann, M. Meyer, and H. Thoenen. 1987. Interleukin-1 regulates synthesis of nerve growth factor in non-neuronal cells of rat sciatic nerve. Nature (Lond.). 330:658-659.

9. Shelton, D. L., and L. F. Reichardt. 1984. Expression of the $\beta$-nerve growth factor gene correlates with the density if sympathetic innervation in effector organs. Proc. Natl. Acad. Sci. USA. 81:79517955.

10. Heumann, R., S. Korsching, J. Scott, and H. Thoenen. 1984. Relationship between levels of nerve growth factor (NGF) and its messenger RNA in sympathetic ganglia and peripheral target tissues. EMBO (Eur. Mol. Biol. Organ.) J. 3:3183-3189.

11. Weskamp, G., and U. Otten. 1987. An enzyme-linked immunoassay for nerve growth factor (NGF): a tool for studying regulatory mechanisms involved in NGF production in brain and in peripheral tissues. J. Neurochem. 48:1779-1786.

12. Davies, A. M., C. Bandtlow, R. Hermann, S. Korsching, H. Rohrer, and $H$. Thoenen. 1987. Timing and site of nerve growth factor synthesis in developing skin in relation to innervation and expression of the receptor. Nature (Lond.). 326:353-358.

13. Yuspa, S., P. Hawley-Nelson, B. Loehler, and J. R. Stanley. 1980. A survey of transformation markers in differentiation epidermal cell lines in culture. Cancer Res. 40:4694-4703.

14. Sauder, D. N., C. S. Carter, S. I. Katz, and J. J. Oppenheim. 1984. Epidermal cell production of thymocyte activating factor (ETAF). J. Invest. Dermatol. 132:828-832.

15. Coughlin, M. D., E. M. Bloom, and I. B. Black. 1981. Characterization of a neuronal growth factor from mouse heart-cell-conditioned medium. Dev. Biol. 82:56-68.

16. Coughlin, M. D., and M. Collins. 1985. Nerve growth factorindependent development of embryonic mouse sympathetic neurons in dissociated cell culture. Dev. Biol. 110:392-401.

17. Matsuda, H., M. Coughlin, J. Bienenstock, and J. A. Denburg. 1988. Nerve growth factor promotes hemopoietic colony growth and differentiation. Proc. Natl. Acad. Sci. USA. 85:6508-6512.

18. Mobley, W. C., A. Schenker, and E. M. Shooter. 1976. Characterization and isolation of proteolytically modified nerve growth factor. Biochemistry. 15:5543-5551.

19. Maniatis, T., E. F. Fritsch, and J. Sumbrook. 1982. Molecular Cloning. Cold Spring Harbor Laboratory, Cold Spring Harbor, NY.

20. Harley, C. B. 1987. Hybridization of oligo (dt) to RNA on nitrocellulose. Gene Anal. Tech. 4:17-22.

21. Feinberg, A. P., and B. Vogelstein. 1983. A technique for radiolabelling DNA restriction endonuclease fragments to high specific activity. Anal. Biochem. 132:6-13.

22. Chan, K. Y., and R. H. Haschke. 1985. Specificity of a neurotrophic factor from rabbit corneal epithelial cultures. Exp. Eye Res. 41:687-699.

23. Yaar, M., M. Peacocke, J. Bhawan, J. L. Gordon, J. R. Southmayd, and B. A. Gilchrest. 1988. Human keratinocytes contain nerve growth factor: a possible inducer of melanocyte dendricity and tropism. Clin. Res. 36:705. (Abstr.)

24. Ansel, J. C., T. A. Luger, D. Lowry, P. Perry, D. R. Roop, and J. D. Mountz. 1988. The expression and modulation of IL- $1 \alpha$ in murine keratinocytes. J. Immunol. 140:2274-2278.

25. Kupper, T. S., A. O. Chua, P. Flood, J. McGuire, and U. Gubler. 1987. Interleukin gene expression in cultured human keratinocytes is augmented by ultraviolet irradiation. J. Clin. Invest. 80:430-436.

26. Peacocke, M., M. Yaar, C. P. Mansur, M. V. Chao, and B. A. Gilchrest. 1988. Induction of nerve growth factor receptors on cultured human melanocytes. Proc. Natl. Acad. Sci. USA. 85:5282-5286. 